\title{
Implementasi Nilai-Nilai Nasionalisme Pada Siswa Sekolah Dasar di Sekolah Indonesia Singapura
}

\author{
Novita Septiyani ${ }^{1}$ Nidar Yusuf ${ }^{2}$ \\ ${ }^{1}$ Prodi PGSD, Universitas Muhammadiyah Jakarta \\ Email: novitadkseptian@gmail.com \\ ${ }^{2}$ Prodi PGSD, Universitas Muhammadiyah Jakarta \\ Email: humaira.alnidrus@gmail.com
}

\begin{abstract}
This study aims to teach nationalism from an early age, which is deemed necessary as the development of a national education system that can distinguish various differences. Especially at the Indonesian School of Singapore, which is located in Singapore. Data collection techniques in this study were carried out with qualitative methods. Data was collected by observation, interviews, and documentation. The subjects in the study were principals, teachers, and fifth grade students at elementary schools at the Singapore Indonesia School. The results of this study indicate that the implementation of the values of nationalism in the Singapore Indonesia School has been running well. Students can implement the value of nationalism which consists of 1) the value of tolerance, (2) the value of responsibility, (3) the value of mutual cooperation, (4) the value of courtesy, (5) the value of being willing to sacrifice when carrying out learning at school. To maximize its implementation, the school provides useful learning with Indonesian citizenship, then organizes extracurricular programs, and has a $5 i$ program.
\end{abstract}

Keywords : Implementation of Nationalism Values, Elementary School Students, Singapore Indonesian School.

\begin{abstract}
Abstrak. Penelitian ini bertujuan untuk mengajarkan nasionalisme sejak dini, yang mana dirasa perlu sebagai pengembangan sistem pendidikan nasional yang dapat menyatukan berbagai perbedaan, Khususnya di Sekolah Indonesia Singapura, yang terletak di negara Singapura. Teknik pengumpulan data pada penelitian ini dilakukan dengan metode kualitatif. Pengumpulan data dilakukan dengan observasi, wawancara, dan dokumentasi. Subjek dalam penelitian adalah kepala sekolah, guru, serta siswa kelas V pada sekolah dasar di Sekolah Indonesia Singapura. Hasil pada penelitian ini menunjukkan bahwa implementasi nilai-nilai nasionalisme di Sekolah Indonesia Singapura sudah dapat berjalan dengan baik. Siswa dapat mengimplementasikan nilai nasionalisme yang terdiri atas 1) nilai toleransi, (2) nilai tanggung jawab, (3) nilai gotong royong, (4) nilai sopan santun, (5) nilai rela berkorban pada saat melaksanakan pembelajaran di sekolah. Untuk memaksimalkan implementasinya, sekolah menyediakan pembelajaran yang berkaitan dengan kewarganegaraan Indonesia, kemudian mengadakan program ekstrakurikuler, serta memiliki program $5 i$.
\end{abstract}

Kata Kunci : Implementasi Nilai-nilai Nasionalisme, Siswa Sekolah Dasar, Sekolah Indonesia Singapura.

\section{PENDAHULUAN}

Pendidikan menurut Anwar (2015) merupakan usaha yang dilakukan oleh manusia untuk menumbuhkan dan mengembangkan potensi jasmani dan rohani, dengan mengedepankan nilai-nilai yang terdapat pada kehidupan bermasyarakat dan berbudaya. Inti dari pendidikan adalah mendidik dan membina siswa untuk dapat tumbuh dan berkembang, serta mampu menjalankan kehidupannya kelak (Wardhana et al., 2020). Menurut Furqan et al. (2020), pendidikan merupakan salah satu bentuk manusia untuk menunjukkan rasa cintanya terhadap negara. Melalui pendidikan, manusia dapat terbebas dari bangsa penjajah, khususnya dari segala perilaku yang dapat merusak persatuan bangsa dan negara. Seperti yang dijelaskan dalam Al-Qur'an Surah At-Taubah ayat 122:

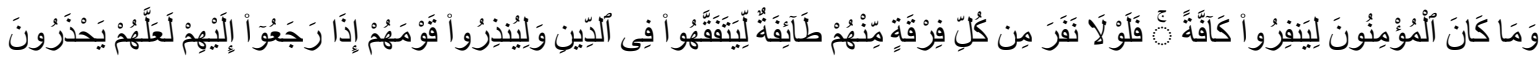


"Dan tidak sepatutnya orang-orang mukmin itu semuanya pergi (ke pertempuran). Mengapa sebagian dari setiap golongan di antara mereka tidak pergi untuk memperdalam pengetahuan agama mereka dan untuk memberi peringatan kepada kaumnya apabila mereka telah kembali, agar mereka dapat menjaga dirinya." (QS. Al-Taubah [9]: 122).

Ayat Al-Qur'an di atas, menjelaskan bahwa, tiap-tiap manusia memiliki kewajiban untuk mencari ilmu, melalui ilmu bangsa dapat terus mempertahankan tanah airnya, dan tidak ada mudah dijajah oleh bangsa lain.

Ayat tersebut menyiratkan manusia untuk dapat mencintai negerinya sendiri. Mencintai negeri berarti memiliki sikap cinta tanah air, dan selalu siap untuk membela tanah air. Dalam hal pendidikan, sikap cinta tanah air ini dapat disebut sebagai Nasionalisme. Nasionalisme merupakan satu paham yang memiliki arti dalam menciptakan dan mempertahankan kedaulatan sebuah negara, mewujudkan tujuan bangsa bersama dan meraih cita-cita demi kepentingan nasional, agar tetap dapat mempertahankan negaranya (Rambe et al., 2019). Setiap masyarakat Indonesia perlu untuk memiliki sikap yang berlandasakan nilai nasionalisme, agar dapat mempertahankan kedaulatan negara dan identitas dari negaranya (Indraswati, 2020).

Sikap nasionalisme dapat dipupuk sedini mungkin. Pelaksanaannya dapat dilakukan di tingkat sekolah dasar (SD), yang merupakan lembaga formal paling dasar, yang memiliki peranan penting dalam menanamkan nilai-nilai nasionalisme di sekolah. Sikap nasionalisme atau cinta tanah air di Indonesia, termasuk pada delapan belas nilai budaya dan karakter bangsa versi Kementerian Pendidikan yang perlu diimplementasikan di sekolah. Implementasi nilai nasionalisme di sekolah dapat dijadikan sebagai titik awal timbulnya rasa harga diri, rasa bangga, dan rasa memiliki terhadap bangsa dan tanah air (Juliyati, 2021). Selain itu, nilai nasionalisme juga dapat memberikan pondasai moral kepada siswa untuk selalu menjadi siswa yang santun dan bertanggung jawab (Al Inu, 2021).

Jika hal ini diterapkan kepada siswa, maka siswa menjadi pribadi yang baik, dengan menjadi warga negara yang patuh terhadap tata tertib dan peraturan yang ada di sekolah, siswa memiliki sikap menghormati guru, orang tua, dan pahlawan yang telah guru, serta melaksanakan kegiatan yang berhubungan dengan nilai nasionalisme seperti upacara bendera, sebagai bentuk cinta tanah air (Muchlis, 2020). Dengan begitu maka dapat meminimalisir terjadinya krisis nilai nasionalisme (Arfadila, 2021).

Oleh sebab itu, penting halnya nilai-nilai nasionalisme dimiliki oleh siswa. Implementasi nilai nasionalisme di sekolah dapar dilakukan dengan pembiasaan (Kutsianto, 2014). Pembiasaan merupakan kegiatan yang dilakukan berilang-ulang, yang bertujuan untuk membentuk sikap (Kutsianto, 2014). Kegiatan pembiasaan dapat dilakukan dengan melaksanakan kegiatan pembelajaran di sekolah, misalnya dengan memberikan materi pembelajaran yang berkaitan dengan nilai-nilai nasionalisme seperti kewarganegaraan, sejarah, dan budaya. Kemudian, memberikan kegiatan yang memiliki keterkaitan dengan nilai-nilai nasionalisme seperti, pramuka dan upacara bendera, dan lain sebagainya. Kegiatan ini dapat menjadi sebuah pembiasaan dalam memberikan pemahaman kepada siswa untuk belajar menghargai jasa para pejuang, serta memahami perbedaan keberagaman yang ada di antara mereka.

Lestari (2018) pada hasil penelitiannya mengungkapkan bahwa, implementasi nilai-nilai nasionalisme pada siswa dapat ditanamkan melalui pembelajaran di kelas. Kemampuan guru dalam mengaitkan contoh nyata dan menerapkan materi di kelas, dapat membuat siswa lebih memahami makna dari nilai-nilai nasionalisme. Hal tersebut juga dapat membangkitkan kesadaran mereka dalam mengenal dan menerapkan nilai-nilai nasionalisme pada kehidupan sehari-harinya.

Pada penelitian ini, peneliti ingin melihat dan mengetahui penanaman nilai-nilai nasionalisme yang dilakukan oleh sekolah kepada siswa sekolah dasar yang bersekolah di sekolah Indonesia Singapura. Meskipun Singapura secara geografis sangat dekat dengan Indonesia, namun secara umum Singapura sudah memiliki kebudayaan tersendiri dan lebih dikenal dengan negara multietnis yang sebelumnya adalah negara Persemakmuran Inggris yang sedikit banyak mengadopsi nilai budaya dan kultur Barat, di sisi lainnya Singapura banyak sekali imigran dari beragam suku bangsa 
lainnya, antara lain Singapura didominasi oleh China yaitu 76,0\%, 15,0\% Melayu, 7.5\% India dan 1,5\% etnis lainnya (www.gov.sg, diakses pada 5 April 2021).

Keberagaman diatas memperlihatkan bahwa rasa persatuan dan kesatuan pada suatu negara akan semakin kuat apabila setiap warga negaranya dapat bersatu dan saling bantu-membantu dalam membangun bangsa. Maka, disinilah fungsi suatu pendidikan nasionalisme diajarkan pada siswa perlu diberikan sejak dini. Karena upaya membangun bangsa, adalah hal yang harus terus dilakukan, melalui pendidikan. Sebab pendidikan merupakan salah satu tujuan bangsa, yakni dalam Kebijakan Pendidikan Nasional Indonesia, bahwa pendidikan adalah upaya yang dapat dilakukan untuk menanamkan dan memelihara kesadaran nasional, yang juga dapat dijadikan sebagai identitas negara.

\section{METODE PENELITIAN}

Penelitian ini adalah penelitian yang menggunakan pendekatan kualitatif dengan metode deskriptif, dimana merupakan suatu metode penelitian yang berusaha menggambarkan sesuai dengan apa adanya. Kemudian dilakukan pemaparan dan analisis kondisi serta pemetaan permasalahan yang terjadi, untuk mengetahui bagaimana implementasi nasionalisme di Sekolah Indonesia Singapura (SIS).

Subjek data pada penelitian merupakan informan yang membantu peneliti dalam mengumpulkan data. Subjek dalam penelitian ini terdiri atas 1 kepala sekolah di Sekolah Indonesia Singapura, 2 guru kelas di kelas $V$, 4 guru pembimbing, dan 6 siswa kelas $V$.

Teknik pengumpulan data dilakukan 1) Observasi dilakukan agar peneliti dapat mengetahui implementasi penanaman nilai-nilai nasionalisme di Sekolah Indonesia Singapura. Untuk itu, peneliti akan secara langsung terlibat dalam kegiatan antara guru dan siswa di sekolah. Peneliti dapat melakukan pencermatan kondisi dari proses pembelajaran yang menanamkan nilai-nilai nasionalisme di Sekolah Indonesia Singapura, untuk kemudian dilakukan beragam analisis pada aspeknya sehingga bisa diketahui hambatan-hambatan dan bagaimana solusinya. Teknik yang kedua adalah melalui 2) Wawancara semi terstuktur dengan menggunakan panduan wawancara yang sebelumnya telah disusun oleh peneliti. Informan pada wawancara terdiri atas kepala sekolah, 2 guru kelas di kelas V, 4 guru pembimbing, dan 6 siswa kelas V. Teknik yang ketiga adalah 3) Dokumentasi, yakni dengan mengumpulkan foto, serta dokumen-dokumen penunjang data pada penelitian, yang berkaitan dengan penanaman nilai-nilai nasionalisme di Sekolah Indonesia Singapura.

Teknik analisis data dilakukan dengan menggunakan Model Miles and Huberman, yakni dengan mereduksi data, menyajikan data, menarik kesimpulan, menganalisis, dan menyajikannya data menurut Sugiyono (2015). Kemudian untuk untuk mendapatkan hasil penelitian yang valid, reliabel, dan obyektif, peneliti melakukan uji keabsahan data dengan menggunakan triangulasi teknik. Triangulasi teknik dilakukan dengan mengecek data yang terdiri atas wawancara, observasi, dan dokumentasi.

\section{HASIL PENELITIAN DAN PEMBAHASAN}

Berdasarkan data yang hasil temuan yang dilakukan melalui observasi, wawancara, dan dokumentasi, maka peneliti akan membahas mengenai implementasi nilai-nilai nasionalisme yang yang dilakukan oleh sekolah kepada siswa sekolah dasar yang bersekolah di sekolah Indonesia Singapura. Adapun hasil dan pembahasannya adalah sebagai berikut.

\section{Hasil Penelitian}

a. Pembelajaran d Kelas Implementasi Nilai-Nilai Nasionalisme di Sekolah Indonesia Singapura Pembelajaran di kelas yang terdapat di Sekolah Indonesia Singapura, terintegrasi pada pembelajaran yang mengedepankan nilai-nilai Nasionalisme, dengan mengimplementasikan nilai Pancasila yang meliputi (1) ketuhanan, kemanusiaan, persatuan, kerakyatan, dan 
keadilan; (2) nilai rela berkorban; (3) nilai toleransi; (4) nilai tanggung jawab; (5) nilai sopan santun; dan (6) nilai gotong royong.

Nilai-nilai ini kemudian dijadikan sebagai sebuah kebiasaan yang diterapkan dalam pembelajaran. Artinya, pada setiap Kompetensi Dasar (KD) terdapat muatan-muatan karakter yang mendukung nilai-nilai Nasionalisme. Misalnya pada pelajaran Pendidikan dan Kewarganegaraan (PKN), IImu Pengetahuan Sosial (IPS), Seni \& Prakarya, Bahasa Indonesia dan sebagainya.

Terkait mata pelajaran tersebut, siswa juga mengaku sangat antusias dalam mengikuti pembelajaran khususnya PKN dan IPS, sebab melalui mata pelajaran PKN dan IPS, siswa dapat tahu banyak hal tentang negaranya, seperti nama-nama pulau yang sangat beragam, negara maritim, luas negara Indonesia, rempah-rempah yang ada di Indonesia, dan mengetahui sejarah Indonesia.

Berdasarkan hasil penelitian, implementasi dari nilai Nasionalisme khususnya pada nilai toleransi kepada siswa dilakukan dengan pelaksanaan pembelajaran khususnya pada mata pelajaran Pendidikan Agama, PKN, dan IPS. Pada mata pelajaran tersebut guru selalu berusaha secara maksimal memberikan pembelajaran yang berkaitan dengan ragam budaya, suku, agama, serta letak geografis yang terdapat di Indonesia. Dengan begitu, melalui pembelajaran yang berlangsung, siswa dapat memiliki pemahaman tentang keanekaragaman budaya, suku, serta agama yang ada di Indonesia guna memperkuat rasa persatuan dan kesatuan serta rasa saling menghargai antara perbedaan tersebut.

Pada nilai tanggung jawab, implementasi dari pelaksanaan nilai Nasionalisme dilakukan dengan mengarahkan siswa untuk memiliki sikap tanggung jawab. Seperti halnya yang terjadi di sekolah adalah, (1) bertanggung jawab dalam mengerjakan PR, (2) bertanggung jawab dalam mengerjakan soal dan tugas yang diberikan guru di kelas, (3) bertanggung jawab dengan program ekstrakurikuler yang diikutinya dengan selalu hadir, (4) bertanggung jawab untuk selalu datang ke sekolah tepat waktu.

Pada nilai gotong royong, implementasi dari nilai Nasionalisme diimplementasikan pada siswa dalam kegiatan, mengerjakan tugas kelompok yang diberikan oleh guru, mempresentasikan tugas secara berkelompok, dan menampilkan performance secara berkelompok.

Pada nilai rela berkorban, implementasi dari nilai Nasionalisme terlihat pada ketika siswa diminta untuk menyumbangkan sebagian uang jajannya untuk korban bencana alam yang terjadi di Mamuju. Pihak OSIS yang menarik dana bantuan, tidak memaksa siswa memberikan nominal yang banyak untuk menyumbangkan sebagian uang jajannya. Namun beberapa siswa terlihat antusias menyisihkan sedikit uang jajannya untuk ikut membantu korban bencana alam di Mamuju.

Pada nilai sopan santun, implementasi dari nilai Nasionalisme, dilakukan dengan mengarahkan siswa untuk selalu menjalin komunikasi yang baik dengan orang tua, guru, serta orang lain yang mereka temui. Siswa perlu memperhatikan tata bahasa dan perilaku yang baik ketika sedang menjalin komunikasi dengan lawan bicaranya.

Berdasarkan hasil penelitian di atas mengenai implementasi nilai-nilai Nasionalisme dalam pembelajaran yang meliputi sikap taqwa kepada Tuhan, toleransi, bertanggung jawab, bergotong royong. rela berkorban, serta, sopan dan santun di SIS sudah cukup baik. Namun di samping itu, demi memaksimalkan penyelenggaraan pembelajaran yang fokus pada impelementasi nilai-nilai Nasionalisme, SIS juga menyelenggarakan kegiatan yang berhubungan dengan penenaman nilai tersebut seperti melaksanakan kegiatan ekstrakurikuler dan program 5-i.

\section{b. Ekstrakurikuler}

Program Ekstrakurikuler merupakan program dengan kegiatan yang dilaksanakan di luar kelas atau di luar jam pembelajaran. Terselenggaranya program ini bertujuan untuk memupuk nilai toleransi, nilai tanggung jawab, nilai rela berkorban, dan nilai gotong royong. Program ini 
adalah salah satu program yang terdapat pada kurikulum pembelajaran yang diterapkan di Indonesia.

Program ekstrakurikuler yang mengajarkan tentang nilai-nilai Nasionalisme yang ada di Indonesia adalah Pramuka, yakni melalui dasa dharma pramuka. Melalui program ini siswa dapat mengimplementasikan nilai Nasionalisme yang terdiri atas toleransi, tanggung jawab, rela berkorban, dan gotong royong. Sebab pelaksanaan kegiatannya dilaksanakan secara berkelompok dan membutuhkan kekompakan untuk mendapatkan hasil maksimal dari kegiatan tersebut.

Program ekstrakurikuler selnajutnya adalah gamelan dan tari, yang bertujuan untuk memperkenalkan ragam budaya dan seni yang ada di Indonesia. Demi memaksimalkan program ekstrakurikuler seni tari tradisional, pihak sekolah menyediakan berbagai macam sarana serta fasilitas yang dibutuhkan siswa, antara lain ruangan latihan, kostum pentas, dan segala perlengkapan yang dibutuhkan siswa dalam pelaksanaan program tersebut. Begitu juga dengan program ekstrakurikuler seni musik, pihak sekolah juga menyediakan berbagai macam sarana serta fasilitas yang dibutuhkan siswa untuk memaksimalkan pelaksanaan kegiatan, seperti seperangkat alat musik gamelan, rebana, angklung, serta alat musik band lengkap dengan gitar, bass, keyboard, dan drum set.

\section{c. Program 5-i}

Program 5-i merupakan program khusus yang dimiliki oleh Sekolah Indonesia Singapura. Program 5-i di SIS merupakan salah satu program yang dibuat untuk memaksimalkan penanaman nilai-nilai Nasionalisme kepada siswa, yakni nilai rela berkorban, nilai toleransi, nilai tanggung jawab, nilai sopan santun, serta nilai gotong royong. Dimana pada nilai-nilai tersebut juga terkandung dalam Pancasila. Berikut ini penjabaran program 5-i, berdasarkan hasil temuan.

\section{1) Senin Cinta Negeri}

Senin cinta negeri merupakan program yang dilaksanakan pada setiap hari senin. Kegiatan yang dilaksanakan pada program ini adalah Apel, Upacara, dan pengibaran bendera merah putih yang dilakukan oleh tim paskibraka.

Apel wajib dilaksanakan oleh seluruh siswa serta kepala sekolah dan guru. Tujuannya adalah untuk mengenang jasa pahlawan yang telah gugur dalam mempertahankan kemerdekaan negara Indonesia. Kegiatan ini rutin dilaksanakan pada setiap pagi, setiap hari selama 10 menit, sebelum siswa memulai pembelajaran di dalam kelas. Kegiatan yang dilaksanakan pada saat Apel adalah menyanyikan lagu Kebangsaan dan lagu Nasional (seperti lagu kebangasaan Indonesia Raya dan Maju Tak Gentar). Pelaksanaan dari Apel pagi, dirasa dapat memupuk nilai Nasionalisme khususnya pada nilai tanggung jawab kepada siswa. Sebab, untuk dapat mengikuti Apel, siswa tidak boleh datang terlambat.

Kemudian pada kegiatan Upacara dan pengibaran bendera merah putih merupakan kegiatan yang bertujuan untuk memperkuat rasa persatuan dan kesatuan siswa terhadap negara Indonesia, serta memberikan pengalaman kepada siswa akan kegiatan yang dulunya sering dilakukan oleh pejuang yang memperjuangkan kemerdekaan negara Indonesia. Dalam melaksanakan kegiatan upacara siswa juga menyanyikan lagu daerah yang terdapat di daerah yang ada di Indonesia, dan lagu nasional kebangsaan Indonesia.

Melalui kegiatan tersebut, siswa dapat mengimplementasikan nilai Nasionalisme, khususnya pada nilai rela berkorban dan tanggung jawab pada pelaksanaan Upacara. Dan bagi tim paskibraka, mereka dapat mengimplementasikan nilai Nasionalisme, khususnya pada nilai tanggung jawab dan gotong royong. 


\section{2) Selasa Literasi}

Selasa literasi merupakan program yang dilaksanakan pada setiap hari selasa, tepatnya pada saat pagi hari. Kegiatan yang dilaksanakan pada program ini adalah membiasakan siswa untuk membaca buku. Tujuan dari progam ini adalah untuk meningkatkan pengetahuan siswa dengan membaca dan menangkap berbagai macam informasi yang didapatkan dari membaca. Demi memaksimalkan pelaksanaan program ini, sekolah menyediakan fasilitas berupa ruang perpustakaan untuk siswa.

Bentuk implementasi terhadap nilai Nasionalisme dari program ini adalah bahwa sekolah mencoba mengarahkan siswa untuk menjadi seseorang yang bertanggung jawab dalam meningkatkan pengetahuannya, memiliki semangat juang yang tinggi dengan belajar sungguh-sungguh.

\section{3) Rabu Komunikasi}

Rabu komunikasi merupakan program yang dilaksanakan pada setiap hari Rabu, selama siswa berada di sekolah. Baik dalam kegiatan pembelajaran maupun kegiatan di luar pembelajaran. Program Rabu komunikasi bertujuan untuk meningkatkan komunikasi siswa khusunya dengan menggunakkan basaha Inggris. Karena selain mengenal bahasa sendiri yakni bahasa Indonesia, siswa juga perlu paham sert a mampu menguasai bahasa universal yakni bahasa Inggris, agar kemampuan komunikasi siswa dapat terus berkembang.

Bentuk implementasi terhadap nilai Nasionalisme dari program ini adalah toleransi. Sebab ketika siswa berkomunikasi dengan orang lain, akan banyak terjadi perbedaan pendapat.

\section{4) Kamis Prestasi}

Kamis prestasi merupakan program yang dilaksanakan pada setiap hari Kamis, tepatnya pada saat pagi hari. Kegiatan yang dilaksanakan pada program ini adalah membantu siswa dalam menuangkan bakatnya di bidang seni, baik seni musik ataupun seni tari.

Program Kamis prestasi bertujuan untuk memperkenalkan ragam budaya yang terdapat di negara Indonesia. Seperti contohnya menyanyikan lagu daerah dan bermain alat musik daerah. Hal ini merupakan salah satu bentuk implementasi terhadap nilai-nilai Nasionalisme khususnya pada nilai toleransi, nilai tanggung jawab, dan nilai gotong royong. Sebab selain mengenal keberagaman yang ada di Indonesia, siswa dituntut untuk dapat tampil di atas panggung dan saling bekerja sama antar siswa lainnya, agar dapat menampilkan performance secara maksimal.

\section{5) Jum'at Religi}

Jumat religi merupakan program yang dilaksanakan pada setiap hari Jumat. Kegiatan yang dilaksanakan pada program ini adalah sholat berjamaah untuk siswa yang beragama islam, sedangkan siswa non muslim belajar agama di kelas bersama guru agamanya masing-masing.

Program ini bertujuan untuk memberikan pengalaman kepada siswa dalam menjalankan kewajiban dari agamanya. Melalui program ini siswa diharapkan mampu mengembangkan dirinya sejalan dengan norma-norma agama, menumbuh kembangkan akhlak mereka sehingga dapat menjadi insan yang proaktif terhadap segala permasalahan yang ada.

Program jumat religi termasuk pada nilai Pancasila yakni ketuhanan. Bentuk implementasi dari nilai Nasionalisme dari program ini adalah dimilikinya nilai toleransi, tanggung jawab, sopan santun pada siswa. Sebab program religi sendiri memiliki banyak sekali manfaat salah satunya adalah memberikan ruang pengembangan diri bagi siswa yang berorientasi pada pembentukan manusia cerdas spiritual, emosional, sosial, intelektual, kinestetis dan estetis, dalam kehidupannya di masyarakat. 


\section{Pembahasan}

\section{Hambatan dan Solusi dalam Implementasi Nilai-Nilai Nasionalisme di Sekolah Indonesia Singapura}

\section{a) Hambatan Internal}

1) Kurangnya tenaga pendidik untuk siswa SD. Solusi dari permasalahan ini hampir semua guru mengampu semua tingkatan.

2) Media untuk kegiatan pembelajaran masih sangat terbatas, tidak semua materi dapat dicontohkan secara langsung seperti materi tentang lingkungan di Indonesia dan contoh kegiatan petani di sawah. Solusinya dari permasalahan ini pihak sekolah masih mengusahakan dengan media berupa video.

3) Kesulitan dalam mencari narasumber, atau sosok-sosok yang menginspirasi dan pelatih ekstrakurikuler. Seperti sulitnya mencari pelatih untuk ekstrakurikuler pada seni musik yakni gamelan. Solusi dari permasalahan ini meminta bantuan KBRI atau mencari sendiri seperti pelatih untuk ekstrakurikuler, yang di datangkan dari Batam.

\section{b) Hambatan Eksternal}

Hambatan yang berasal dari orang tua campuran, yakni antara kewarganegaraan Indonesia dengan kewarganegaraan asing. Apabila ada orang tua yang berasal dari perkawinan campuran, ada salah satu yang mendukung pelaksanaan penanaman nilai-nilai Nasionalisme di sekolah. Begitupun sebaliknya, ada yang tidak setuju.

Solusi dari permasalahan tersebut adalah dengan mengupayakan semaksimal mungkin program sekolah yaitu program $5-i$, untuk menumbuhkan sikap toleransi. Solusi lain juga dapat dilakukan dengan: (1) mengajarkan siswa dalam menyanyikan lagu nasional dan daerah khas Indonesia, (2) memperkenalkan keanekaragaman budaya yang ada di Indonesia (seperti makanan khas dari tiap-tiap daerah, pakaian adat, dan bahasa daerah, (3) memupuk rasa loyalitas siswa kepada bangsa indonesia dengan memiliki KTP, Kartu Keluarga (KK), Paspor, Akte Kelahiran, yang dibuat di Indonesia, (4) mengajarkan siswa untuk mengikuti pemilu pilpres dan pilkada indonesia, (5) mengajarkan kepada siswa untuk bersedia tunduk dan patuh pada hukum indonesia dimanapun berada baik di dalam negeri maupun di luar negeri, (6) dan mengajarkan kepada siswa untuk berani berkomunikasi dengan siapapun, dan bersaudara dengan warga luar daerah Indonesia dan warga luar negeri.

\section{KESIMPULAN}

Berdasarkan hasil penelitian yang telah dipaparkan dan kemudian dilakukan analisis mengenai Implementasi nilai-nilai Nasionalisme yang terdiri atas (1) nilai toleransi, (2) nilai tanggung jawab, (3) nilai gotong royong, (4) nilai sopan santun, (5) nilai rela berkorban, pada siswa Sekolah Dasar di Sekolah Indonesia Singapura, khususnya pada siswa kelas V. Maka dapat disimpulkan bahwa.

1. Pemahaman siswa terhadap nilai Nasionalisme sudah cukup baik. Siswa sangat bangga menjadi warga negara Indonesia, sebab mereka dapat belajar berbagai macam hal mengenai budaya yang ada di Indonesia, seperti alat musik tradisional, tarian tradisional, lagu-lagu tradisional, senjata tradisional, pakaian adat, dan lain sebagainya. Selain itu, siswa juga masih menggunakan Bahasa Indonesia sebagai Bahasa keseharian mereka ketika berkomunikasi dan melakukan interaksi di sekolah.

2. Implementasi siswa terhadap nilai-nilai Nasionalisme di sekolah, sudah cukup baik. Siswa dapat mengimplementasikan nilai Nasionalisme yang terdiri atas (a) nilai toleransi, (b) nilai tanggung jawab, (c) nilai gotong royong, (d) nilai sopan santun, (e) nilai rela berkorban pada saat melaksanakan pembelajaran di sekolah, baik pada pembelajaran di dalam kelas, maupun diluar kelas seperti program ekstrakurikuler dan program 5i. Adanya program ekstrakurikuler dan program $5 \mathrm{i}$, sangat membantu pemahaman siswa akan nilai Nasionalisme yang mana sangat penting untuk diterapkan dalam kehidupan sehari-harinya.

3. Hambatan yang dialami yakni, hambatan internal yang meliputi (a) Terbatasnya pendidik ataupun guru untuk mengajar siswa di sekolah dasar. Solusi permasalahan ini adalah 
menugaskan semua guru untuk mengampu semua tingkatan. (b) Media pembelajaran yang terbatas. Solusinya pihak sekolah masih mengusahakan dengan media berupa video-video pembelajaran. (c) Kesulitan mencari narasumber atau sosok-sosok yang menginspirasi dan pelatih ekstrakurikuler, seperti pelatih untuk ekstrakurikuler pada seni musik yakni gamelan. Solusinya mendatangkan pelatih dari Batam. Kemudian hambatan eksternal berasal dari orang tua campuran, yakni antara kewarganegaraan Indonesia dengan kewarganegaraan asing. Keadaan ini sering kali terjadi pro kontra antara salah satu yang mendukung pelaksanaan penanaman nilai-nilai Nasionalisme di sekolah. Namun ada juga yang tidak mendukung program tersebut. Solusinya adalah dengan mengupayakan semaksimal mungkin program sekolah yaitu program 5-i, untuk menumbuhkan sikap toleransi.

\section{DAFTAR PUSTAKA}

An Nisaa'an Najm Al Inu \& Dinie Anggraeni Dewi. (2021). Implementasi Nilai Nilai Pancasila Melalui Pendidikan Kewarganegaraan Di Sekolah Dan Di Masyarakat. Jurnal Kewarganegaraan, 5(1), 259-267. https://journal.upy.ac.id/index.php/pkn/article/view/1383

Arfadila, \& Dewi, D. A. (2021). Penanaman Nilai Nasionalisme Kebangsaan Pada Siswa Sd Muhammadiyah Muntok Bangka Barat. Edukasi Tematik: Jurnal Pendidikan Guru Sekolah Dasar, 1(1), 72-79.

Elisa Dwi Juliyati. (2021). Peranan Pembelajaran Sejarah dalam Penanaman Nilai Karakter Nasionalisme. Osf Preprints, 148, 148-162.

Furqan, M. H., Yanti, S., Azis, D., Kamza, M., \& Ruslan, R. (2020). Analisis Konten Nilai Cinta Tanah Air (Nasionalisme) dalam Materi Mata Pelajaran Kurikulum Geografi. Jurnal Serambi IImu, 21(1), 48-63. https://doi.org/10.32672/si.v21i1.1882

Indraswati. (2020). Implementasi Penanaman Nilai-Nilai Nasionalisme di SDN Karanganyar Gunung 02, Candisari, Semarang, Jawa Tengah. Jurnal Rontal Keilmuan, 6(2). https://jurnal.stkippgritulungagung.ac.id/index.php/rontal/article/view/1721

Kutsianto. (2014). Metode Pembiasaan sebagai Media Pembentukan Karakter Anak di TK At Taqwa Balapan Ksatrian Yogyakarta. UIN Sunan Kalijaga.

Muchlis, M., \& Rodja Abdul Natsir, K. (2020). Penanaman Nilai Nasionalisme pada Upacara Bendera. Jurnal Jupekn, 1-5.

Muhammad Anwar. (2015). Filsafat Pendidikan. Kencana.

Rambe, T., Suhendro, P., Syahrul, L., Saragih, N., Khairani, L., Yayasan, P., \& Menulis, K. (2019). Sejarah Politik dan Kekuasaan (Issue October).

Sri Uji Lestari, Ufi Saraswati, A. M. (2018). Penanaman Nilai-nilai Nasionalisme dalam Pembelajaran Sejarah Lokal Perjuangan Rakyat Sukorejo Kelas XI di SMA Negeri 1 Sukorejo. Indonesian Journal of History Education, 6(2), 205-215. https://doi.org/10.21831/istoria.v13i2.17736

Sugiyono. (2015). Metode Penelitian Pendidikan. Alfabeta.

Wardhana, I. P., S, L. A., \& Pratiwi, V. U. (2020). Konsep Pendidikan Taman Siswa sebagai Dasar Kebijakan Pendidikan Nasional Merdeka Belajar di Indonesia. Prosiding Seminar Nasional, 232-242. 